\title{
A Purple Cupredoxin from Nitrosopumilus maritimus Containing a Mononuclear Type 1 Copper Center with an Open Binding Site
}

Parisa Hosseinzadeh, ${ }^{\dagger, \S}$ Shiliang Tian, ${ }^{\star, \S}$ Nicholas M. Marshall, ${ }^{\ddagger}{ }^{\ddagger}$ James Hemp,${ }^{\dagger}$ Timothy Mullen, ${ }^{\ddagger}$ Mark J. Nilges, ${ }^{\ddagger}$ Yi-Gui Gao, ${ }^{\natural}$ Howard Robinson, ${ }^{\|}$David A. Stahl, ${ }^{\&}$ Robert B. Gennis ${ }^{\dagger, * *}$ and Yi Lu ${ }^{\dagger, * *}$

${ }^{\dagger}$ Department of Biochemistry, ${ }^{\ddagger}$ Department of Chemistry, ${ }^{\circledR}$ Biocrystallization Facility, ${ }^{¥}$ EPR Center, University of Illinois at Urbana-Champaign, Urbana, IL 61801, USA

"Biology Department, Brookhaven National Laboratory, Upton, New York 11973-5000, USA.

\& Department of Civil and Environmental Engineering, University of Washington, Seattle, WA 98195

\section{Supplemental information:}

Materials and methods

Cell culture and expression of N. mar proteins

The protein coding DNA sequence of Nmar1307 was cloned into the pET-22b periplasmic expression vector (Novagen) from genomic DNA using the NcoI and XhoI restriction sites. The His-tag was removed by incorporating a stop codon at the XhoI site before the tag. Nmar1307 natively has an Nterminal helix that anchors the protein to the cell membrane. This membrane-associated helix was omitted from the cloned sequence here in order to result in solubly expressed protein. The $\mathrm{pET}-22 \mathrm{~b}$ leader sequence gets cleaved after expression at the Met residue.

Rosetta strain Escherichia coli (Novagen) was then transformed with the cloned sequences and cell stocks were made. This strain of $E$. coli was used because the codon usage of $N$. mar is very different from E. coli and Rosetta cells have extra translational machinery and tRNAs to compensate for this. Transformed cells were then used to streak LB plates with $100 \mathrm{mg} / \mathrm{L}$ ampicillin. These plates were incubated at $37{ }^{\circ} \mathrm{C}$ overnight to obtain single colonies. Single colonies were then used to inoculate $5 \mathrm{~mL}$ LB cultures with $100 \mu \mathrm{g} / \mathrm{mL}$ of ampicillin, which were then incubated at $37^{\circ} \mathrm{C}$ until an $\mathrm{OD}_{600}$ of $0.6-0.8$ was achieved. A $2 \mathrm{~L}$ portion of $2 \mathrm{xYT}$ media was then inoculated with $1 \mathrm{~mL}$ of the $5 \mathrm{~mL}$ culture and 100 $\mathrm{mg} / \mathrm{L}$ of ampicillin. The $2 \mathrm{~L}$ cultures were then incubated at $37^{\circ} \mathrm{C}$ overnight, typically reaching an $\mathrm{OD}_{600}$ of around 1.5 after 18 hours. In the morning, cells were induced with $100 \mathrm{mg} / \mathrm{L}$ of Isopropyl $\beta$-D-1thiogalactopyranoside (IPTG) and allowed to express protein at $37{ }^{\circ} \mathrm{C}$ for an additional 4 hours. After expressing for 4 hours, proteins were extracted via the osmotic shock procedure outlined below.

Osmotic shock procedure for periplasmically expressed N. mar proteins 
The volumes in the procedure outlined below were scaled based on the volume of the original culture. After harvesting the E. coli cells by centrifugation, the cells were re-suspended in $1 / 8$ the volume of the original culture of a solution containing $20 \% \mathrm{w} / \mathrm{v}$ sucrose, $50 \mathrm{mM}$ tris $\mathrm{HCl}$ buffer at $\mathrm{pH} 8.0$, and 5 $\mathrm{mM}$ ethylenediaminetetraacetate (EDTA). The cells were incubated in this solution at room temperature for 1 hour and re-harvested. The supernatant was discarded and the cells were re-suspended in 1/8 the volume of the original culture of a solution with $4 \mathrm{mM} \mathrm{NaCl}$ and $1 \mathrm{mM}$ dithiothreitol (DTT) for 10 minutes at $4{ }^{\circ} \mathrm{C}$ to effectively lyse the periplamsic membrane. Precipitants were then removed by centrifuging and the supernatant was collected. The $\mathrm{pH}$ of the supernatant was then lowered to 4.0 by slowly adding a solution of $500 \mathrm{mM}$ sodium acetate at $\mathrm{pH} 4.0$ (1/10 the volume of the supernatant). Lowering the $\mathrm{pH}$ in this way caused more precipitation, which were again removed by centrifuging and the supernatant was collected.

\section{Column purification of Nmar 1307 and re-constitution with copper}

After extracting the protein from the cells by the osmotic shock procedure above, the $\mathrm{pH}$ of the Nmar1307 supernatant solution was raised to 6.0 by slow addition of aqueous $\mathrm{NaOH}$. The supernatant was then applied to a FF Q-Sepharose column (50 mL, GE Healthcare) equilibrated in $50 \mathrm{mM}$ sodium acetate buffer at $\mathrm{pH} 6.0$ by adding the beads directly to the supernatant and letting it shake on an orbital shaker at 4 ${ }^{\circ} \mathrm{C}$ overnight. The protein was eluted from the column by a $\mathrm{NaCl}$ gradient on an Akta basic FPLC (GE Healthcare). The desired protein typically eluted at around $300 \mathrm{mM} \mathrm{NaCl}$.

Nmar1307 was then reconstituted with copper by adding a slight excess of $\mathrm{CuSO}_{4}$ to the partially purified protein solution. Full incorporation took several hours to complete. It was believed that the slow incorporation of copper compared to some other cupredoxin proteins may have been due to binding of copper ion to other sites. To remove this adventitious metal sites, we added excess EDTA to the protein solution and incubated at $4{ }^{\circ} \mathrm{C}$ with stirring for 1 hour to overnight. The excess EDTA was then removed by a desalting column (for small protein preps) or by the next Q-column (for larger preps). Copper incorporated protein was then separated from non-copper bound protein and other contaminants by reapplying the protein to a Q-Sepharose column and re-eluting it with a $\mathrm{NaCl}$ gradient. The purification finished by applying the protein to a size exclusion column (GE Healthcare). The purity of the final protein solution was assessed with SDS-Page and electrospray ionization mass spectrometry (ESI-MS).

\section{Redox titration of Cu(II)-Nmar1307 with ferrocyanide at $\mathrm{pH} 8$}

The redox titration method was adopted from a previously reported procedure. ${ }^{1} \mathrm{Cu}(\mathrm{II})-\mathrm{Nmar} 1307$ solution in $100 \mathrm{mM}$ Tris $\mathrm{pH} 8.0$ was degassed and equilibrated with Ar on a Schlenk line and was then transferred into an anaerobic chamber (Coy Laboratories). To $1.0 \mathrm{ml}$ of $165 \mu \mathrm{M} \mathrm{Cu}(\mathrm{II})-\mathrm{Nmar} 1307$ solution, different amounts of ferrocyanide solution (from $500 \mathrm{mM}$ stock solution in water) were added at room temperature under stirring. The final concentration of ferrocyanide was at $0.5,1.0,2.0,3.0,4.0$ and 6.0 $\mathrm{mM}$. The UV-vis spectra were monitored on an Agilent 8453 photodiode array spectrometer, located inside the anaerobic chamber, after each addition of ferrocyanide. The reduction of $\mathrm{Cu}(\mathrm{II})-\mathrm{Nmar} 1307$ was 
monitored by decreasing LMCT band at $558 \mathrm{~nm}$ where the ferricyanide and ferrocyanide do not contribute to absorption. Corrections are made for dilution. The extinction coefficient at $558 \mathrm{~nm}\left(\varepsilon_{558 \mathrm{~nm}}=2290 \mathrm{M}^{-1}\right.$ $\mathrm{cm}^{-1}$ ) was used to calculate the concentration of $\mathrm{Cu}(\mathrm{II})-\mathrm{Nmar} 1307$ solution. The concentration of $\mathrm{Cu}(\mathrm{I})-$ Nmar1307 was calculated by subtracting the concentration of $\mathrm{Cu}(\mathrm{II})-\mathrm{Nmar} 1307$ from the total concentration of $\mathrm{Cu}-\mathrm{Nmar} 1307(165 \mu \mathrm{M})$. The reduction potential of $\mathrm{Cu}(\mathrm{II})-\mathrm{Nmar} 1307$ was calculated based on Nernst equation by linear plotting the potentials of ferri/ferrocyanin redox pair versus $\log ([\mathrm{Cu}(\mathrm{II}) / \mathrm{Cu}(\mathrm{I})])$. The intercept $(354 \mathrm{mV})$ represents the reduction potential of $\mathrm{Cu}(\mathrm{II})-\mathrm{Nmar} 1307$ at $\mathrm{pH}$ 8.0. The slope of the fitting was $65 \mathrm{mV}$, close to the theoretic value $59 \mathrm{mV}$.

Redox titration of $\mathrm{Cu}(\mathrm{I})$-Nmar1307 with ferricyanide at $\mathrm{pH} 8$

$\mathrm{Cu}(\mathrm{II})$-Nmar1307 solution in $100 \mathrm{mM}$ Tris $\mathrm{pH} 8.0$ was degassed and equilibrated with Ar on a Schlenk line and was then transferred into an anaerobic chamber (Coy Laboratories). The $\mathrm{Cu}$ (II)-Nmar1307 was reduced by adding ascorbate/TMPD (10:1 mixture) solid till the solution turned colorless. The excess ascorbate/TMPD was removed by running the solution through a PD-10 desalting column (GE Healthcare Life Sciences). To $1.0 \mathrm{ml}$ of $570 \mu \mathrm{M} \mathrm{Cu}(\mathrm{I})$-Nmar1307 solution, different amounts of ferricyanide solution (from either $100 \mathrm{mM}$ or $500 \mathrm{mM}$ stock solution in water) were added at room temperature under stirring. The final concentration of ferricyanide was at $0.1,0.2,0.3,0.4,0.5,0.6,0.7,0.8,0.9,1.0,1.2,1.5,2.0,5.0$ and $10 \mathrm{mM}$ respectively. The UV-vis spectra were monitored on an Agilent 8453 photodiode array spectrometer, located inside the anaerobic chamber, after each addition of ferricyanide. The oxidaiton of $\mathrm{Cu}(\mathrm{I})-\mathrm{Nmar} 1307$ was monitored by increasing LMCT band at $558 \mathrm{~nm}$ where the ferricyanide and ferrocyanide do not contribute to absorption. Corrections are made for dilution. The extinction coefficient at $558 \mathrm{~nm}\left(\varepsilon_{558 \mathrm{~nm}}=2290 \mathrm{M}^{-1} \mathrm{~cm}^{-1}\right)$ was used to calculate the concentration of $\mathrm{Cu}(\mathrm{II})-\mathrm{Nmar} 1307$ solution. The concentration of $\mathrm{Cu}(\mathrm{I})-\mathrm{Nmar} 1307$ was calculated by subtracting the concentration of $\mathrm{Cu}(\mathrm{II})$-Nmar1307 from the total concentration of $\mathrm{Cu}-\mathrm{Nmar} 1307(570 \mu \mathrm{M})$. The reduction potential of $\mathrm{Cu}(\mathrm{II})-\mathrm{Nmar} 1307$ was calculated based on Nernst equation by linear plotting the potentials of ferri/ferrocyanin redox pair versus $\log ([\mathrm{Cu}(\mathrm{II}) / \mathrm{Cu}(\mathrm{I})])$. The intercept $(354 \mathrm{mV})$ represents the reduction potential of $\mathrm{Cu}(\mathrm{II})-\mathrm{Nmar} 1307$ at $\mathrm{pH}$ 8.0. The slope of the fitting was $54 \mathrm{mV}$, close to the theoretic value $59 \mathrm{mV}$.

\section{Spectroscopic characterization of Nmar1307}

Electrospray ionization mass spectroscopy (ESI-MS) was collected on a Waters Quattro II Tandem Quadrupole/Hexapole/Quadrupole instrument, maintained by University of Illinois Mass Spectroscopy Facility, by adding formic acid to samples to ionize. UV-visible spectra of Nmar1307 were collected on a Carey 3E (Varian) in $50 \mathrm{mM}$ or $100 \mathrm{mM}$ Tris buffer $\mathrm{pH}$ 8.0. X-band EPR spectra were taken using X-band Varian E-122 spectrometer at the Illinois EPR Research Center (IERC) at $77 \mathrm{~K}$ in the same buffer as a glass with 0,20 , or $60 \%$ glycerol at $1 \mathrm{~mW}$ power and modulation of 4 gauss. For pH-dependent studies the

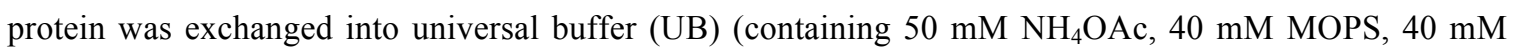
MES and $40 \mathrm{mM}$ Tris) which spans a wide range of $\mathrm{pH}$ with the same ionic composition. Q-band EPR 
spectra were collected on an E580 Elexsys spectrometer with a superQ-FT attachment and an ER5106QT (CW) probe. The samples were collected at a temperature of $77 \mathrm{~K}$, power of $0.047 \mathrm{~mW}$ and modulation of 8 gauss. EPR simulation used the program SIMPOW. ${ }^{2}$ First and second derivative X-band and Q-band spectra were simultaneously fitted to give the lowest sum of the rms residuals for the four spectra.

\section{Cu(II)-Nmar1307 extinction coefficient determination by spin-counting EPR}

The extinction coefficient of absorption bands were calculated based on spin-counting EPR, using $\mathrm{CuSO} 4$ solutions with known concentration as calibration. The total spins in samples were quantified by double integration of the spectrum. A standard curve was obtained by linear fitting of double integrated EPR spectra versus the $\mathrm{CuSO}_{4}$ concentrations. The concentration of $\mathrm{Cu}(\mathrm{II})-\mathrm{Nmar} 1307$ was calculated by dividing the double integrated EPR spectrum of $\mathrm{Cu}(\mathrm{II})$-Nmar1307 by the slope of the linear fitting. UV-vis spectrum of $\mathrm{Cu}$ (II)-Nmar1307 was taken and its extinction coefficient was calculated based on the absorption intensity and concentration of $\mathrm{Cu}(\mathrm{II})-\mathrm{Nmar} 1307$.

Crystallization of Nmar1307, data analysis, and molecular visualization

Crystals of Nmar1307 were grown by the hanging drop vapor diffusion method. Protein solution was prepared in $50 \mathrm{mM}$ sodium acetate buffer at $\mathrm{pH} 6.0$ to a concentration of about $1.5 \mathrm{mM}$. A $2 \mu \mathrm{L}$ portion of this protein solution was then mixed with $2 \mu \mathrm{L}$ of a well buffer solution consisting of $100 \mathrm{mM}$ TrisHCl buffer at $\mathrm{pH} 8.0,20 \mathrm{mM} \mathrm{CuSO}_{4}, 100 \mathrm{mM} \mathrm{LiNO}_{3}$ and varying amounts of polyethylene glycol (PEG). The highest quality crystals formed from wells with $35 \% \mathrm{w} / \mathrm{v}$ PEG 4000 after about 2 months at 4 ${ }^{\circ} \mathrm{C}$. We should note that the reported crystal structure is not at $\mathrm{pH} 6$ but higher because the protein drop was mixed 1:1 with a buffer with high capacity at $\mathrm{pH} 8$.

Data was collected at Brookhaven National Laboratory, beamline X-29A. The data was then indexed using HKL2000 software and phased and refined using Shelx97 and PHENIX ${ }^{3}$ software. Azurin backbone (PDB entry 4AZU) was used as the initial model for refinement. Coot software ${ }^{4}$ was used for analysis of the refined data. Data visualization was performed using $\mathrm{VMD}^{5}$ and pymol visualization packages. The entry channel of waters was predicted using HOLLOW package. ${ }^{6}$

\section{NO oxidation activity of $\mathrm{Cu}(\mathrm{II})$-Nmar1307 at $\mathrm{pH} 8.0$}

$\mathrm{Cu}(\mathrm{II})$ loaded Nmar1307 protein solution in $50 \mathrm{mM}$ Tris $\mathrm{pH} 8.0$ buffer was degassed in a Schlenk line and transferred to an anaerobic chamber (Coy Laboratories). 5 molar equivalents of Proli NONOate solution (Cayman Chemicals, from a $50 \mathrm{mM}$ stock solution in $10 \mathrm{mM} \mathrm{NaOH}$ ) was added to $2000 \mu \mathrm{l}$ of 193 $\mu \mathrm{M} \mathrm{Cu}(\mathrm{II})-\mathrm{Nmar} 1307$ solution in $50 \mathrm{mM}$ Tris $\mathrm{pH} 8.0$ buffer. The UV-vis spectra were monitored on an Agilent 8453 photodiode array spectrometer located inside the anaerobic chamber. The extinction coefficient at $558 \mathrm{~nm}\left(\varepsilon_{558 \mathrm{~nm}}=2290 \mathrm{M}^{-1} \mathrm{~cm}^{-1}\right)$ was used to calculate the concentration of $\mathrm{Cu}$ (II)-Nmar1307 solution. The concentration of Proli NONOate (Cayman Chemical, MI) was determined using $\varepsilon_{252 \mathrm{~nm}}=8400$ $\mathrm{M}^{-1} \mathrm{~cm}^{-1}$. 
EPR spectra were collected at $30 \mathrm{~K}$ on an X-band Varian E-122 spectrometer at the Illinois EPR Research Center equipped with an Air Products Helitran Cryostat and EIP frequency counter. The EPR samples were prepared as described above except higher protein concentration was used for better resolution. Glycerol was added to a final concentration of $20 \% \mathrm{v} / \mathrm{v}$ and the solution was quickly frozen in liquid nitrogen.

pH-dependent activity of $\mathrm{Cu}(\mathrm{II})$-Nmar 1307 reacting with $\mathrm{NO}$

$\mathrm{Cu}$ (II)-Nmar1307 solution in $50 \mathrm{mM}$ MES at pH6.0, $50 \mathrm{mM}$ BisTris at $\mathrm{pH} 7.0$ or $50 \mathrm{mM}$ Tris at pH8.0 was degassed and equilibrated with Ar on a Schlenk line and was then transferred into an anaerobic chamber (Coy Laboratories). To $1.0 \mathrm{ml}$ of $116 \mu \mathrm{M} \mathrm{Cu(II)-Nmar1307} \mathrm{solution,} 13$ molar equivalents of Proli NONOate solution (Cayman Chemicals, from $60 \mathrm{mM}$ Proli NONOate stock solution in $10 \mathrm{mM}$ $\mathrm{NaOH}$ ) was added at room temperature under stirring. The color of the solution changed from purple to colorless. The UV-vis spectra were monitored on an Agilent 8453 photodiode array spectrometer located inside the anaerobic chamber. The extinction coefficient at $558 \mathrm{~nm}\left(\varepsilon_{558 \mathrm{~nm}}=2290 \mathrm{M}^{-1} \mathrm{~cm}^{-1}\right)$ was used to calculate the concentration of $\mathrm{Cu}$ (II)-Nmar1307 solution. The concentration of Proli NONOate (Cayman Chemical, MI) was determined using $\varepsilon_{252 \mathrm{~nm}}=8400 \mathrm{M}^{-1} \mathrm{~cm}^{-1}$.

Measuring reaction rates between $\mathrm{Cu}(\mathrm{II})$-Nmar 1307 and NO at $\mathrm{pH} 8.0$

$\mathrm{Cu}$ (II)-Nmar1307 solution in $50 \mathrm{mM}$ Tris at $\mathrm{pH} 8.0$ was degassed and equilibrated with argon on a Schlenk line and was then transferred into an anaerobic chamber (Coy Laboratories). To $1.0 \mathrm{ml}$ of $58 \mu \mathrm{M}$ $\mathrm{Cu}(\mathrm{II})$-Nmar1307 solution, 6.5, 10.0, 13 or 16 molar equivalents of Proli NONOate solution (Cayman Chemicals, from $60 \mathrm{mM}$ Proli stock solution in $10 \mathrm{mM} \mathrm{NaOH}$ ) was added at room temperature under stirring. The UV-vis spectra were monitored on an Agilent 8453 photodiode array spectrometer located inside the anaerobic chamber. The extinction coefficient at $558 \mathrm{~nm}\left(\varepsilon_{558 \mathrm{~nm}}=2290 \mathrm{M}^{-1} \mathrm{~cm}^{-1}\right)$ was used to calculate the concentration of $\mathrm{Cu}(\mathrm{II})$-Nmar1307 solution. The concentration of Proli NONOate (Cayman Chemical, MI) was determined using $\varepsilon_{252 \mathrm{~nm}}=8400 \mathrm{M}^{-1} \mathrm{~cm}^{-1}$. The concentration of $\mathrm{NO}$ was calculated to be twice of the concentration of Proli NONOate (each Proli NONOate dissociates to form one proline and two NO molecules). The absorption decreasing at $558 \mathrm{~nm}$ was fitted as pseudo-first-order kinetics. The secondorder reaction rates between $\mathrm{Cu}(\mathrm{II})-\mathrm{Nmar} 1307$ and $\mathrm{NO}$ was calculated upon linear fitting of pseudo-firstorder reaction rates at different concentrations of NO.

Oxidation of $\mathrm{Cu}(\mathrm{I})$-Nmar1307 to Cu(II)-Nmar1307 with ferricyanide

$\mathrm{Cu}$ (II)-Nmar1307 solution in $50 \mathrm{mM}$ Tris at $\mathrm{pH} 8.0$ was degassed and equilibrated with $\mathrm{Ar}$ on a Schlenk line and was then transferred into an anaerobic chamber (Coy Laboratories). To $1.0 \mathrm{ml}$ of $116 \mu \mathrm{M}$ $\mathrm{Cu}$ (II)-Nmar1307 solution, 6.5 molar equivalents of Proli NONOate solution (Cayman Chemicals, from 60 $\mathrm{mM}$ Proli stock solution in $10 \mathrm{mM} \mathrm{NaOH}$ ) was added at room temperature under stirring. After the color of the solution changed from purple to colorless, 130 molar equivalents of potassium ferricyanide (from $1 \mathrm{M}$ 
stock of potassium ferricyanide in water) was added under stirring. The UV-vis spectra were monitored on an Agilent 8453 photodiode array spectrometer located inside the anaerobic chamber. The extinction coefficient at $558 \mathrm{~nm}\left(\varepsilon_{558 \mathrm{~nm}}=2290 \mathrm{M}^{-1} \mathrm{~cm}^{-1}\right)$ was used to calculate the concentration of $\mathrm{Cu}$ (II)-Nmar1307 solution. The concentration of Proli NONOate (Cayman Chemical, MI) was determined using $\varepsilon_{252 \mathrm{~nm}}=8400$ $\mathrm{M}^{-1} \mathrm{~cm}^{-1}$ ?

Determination of the product of Cu(II)-Nmar1307 reaction with NO by Griess assay

The Griess reagent kit for nitrite quantitation containing $N$-(1-naphthyl)ethylenediamine dihydrochloride, sulfanilic acid and nitrite standard solution was purchased from Life technologies and stored refrigerated at $4{ }^{\circ} \mathrm{C}$, protected from light. Sodium nitrite standard solutions with concentrations between 1-100 $\mu \mathrm{M}$ were prepared by diluting the nitrite stock solution with Millipore water. Equal volumes of $N$-(1-naphthyl)ethlyenediamine and sulfanilic acid were mixed to form the Griess reagent. A mixture of $10 \mu \mathrm{L}$ of the Griess reagent, $30 \mu \mathrm{L}$ of the nitrite-containing sample and $260 \mu \mathrm{L}$ of Millipore water were incubated for 30 minutes at room temperature. To obtain the standard curve, concentration of nitrite was plotted against the absorbance of the mixture at $548 \mathrm{~nm}$, measured relative to the reference sample containing $10 \mu \mathrm{L}$ Griess reagent and $290 \mu \mathrm{L}$ Millipore water.

To investigate whether the protein produces nitrite, $\mathrm{Cu}(\mathrm{II})-\mathrm{Nmar} 1307$ was mixed with 6.5 molar equivalents Proli NONOate (Cayman Chemicals, MI) solution in $100 \mathrm{mM}$ Tris buffer $\mathrm{pH} 8.0$ according to the procedure described above. After the solution turned colorless, $30 \mu \mathrm{L}$ of the solution was mixed with 10 $\mu \mathrm{L}$ of the Griess reagent and $260 \mu \mathrm{L}$ of Millipore water. In the meantime, a solution of only Proli NONOate in $100 \mathrm{mM}$ Tris buffer $\mathrm{pH} 8.0$ was used as a control, also incubated with Griess reagent at room temperature for $30 \mathrm{~min}$. The absorbance at $548 \mathrm{~nm}$ was then measured and nitrite concentrations were determined by comparing the sample absorbance with those from the standard plot.

\section{Figures:}

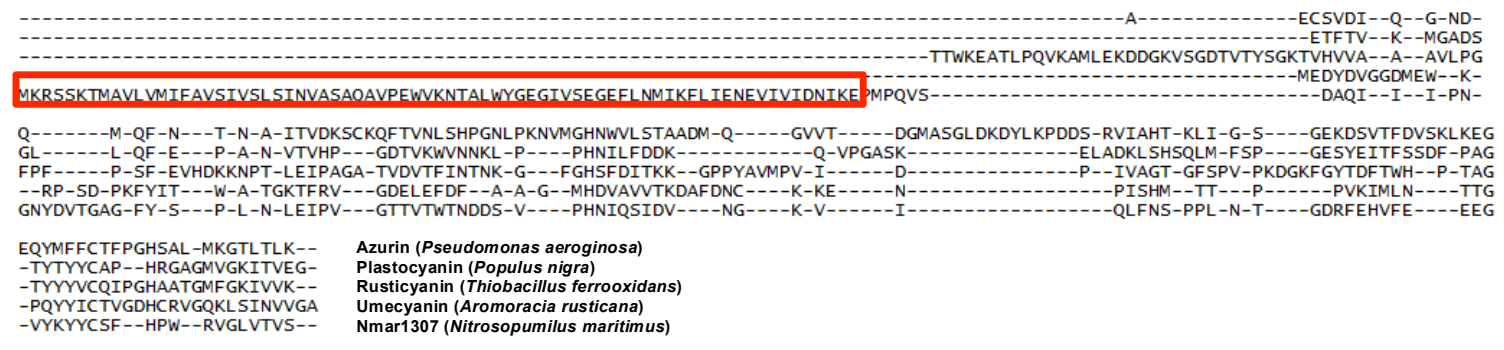

Figure S1. Structure-based sequence alignment of Nmar1307 and a number of other cupredoxins. The initial sequence shown in a red box is the membrane helix that was excluded from the sequence to express the protein in a soluble form. 

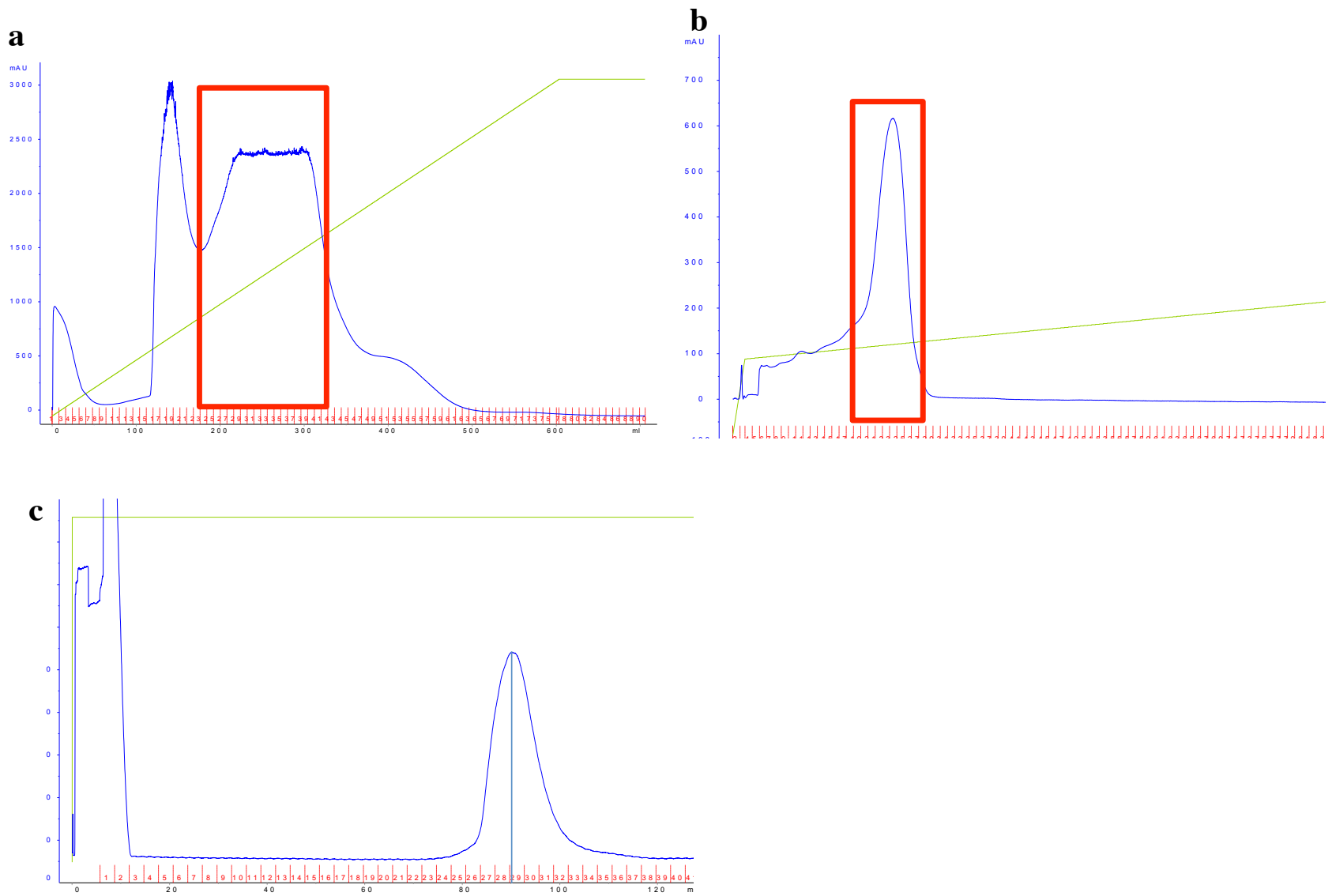

Figure S2. (a) FPLC trace of metal free N. mar-1307 on a Q-column. After metal reconstitution and EDTA treatment, the holo-protein is loaded into a second Q FF column. The trace is shown in (b). (c) shows the SEC trace of the final protein. In all figures, the blue line indicates absorption at $280 \mathrm{~nm}$ and the green line represents the concentration of buffer B. Collected fractions are shown in red box.
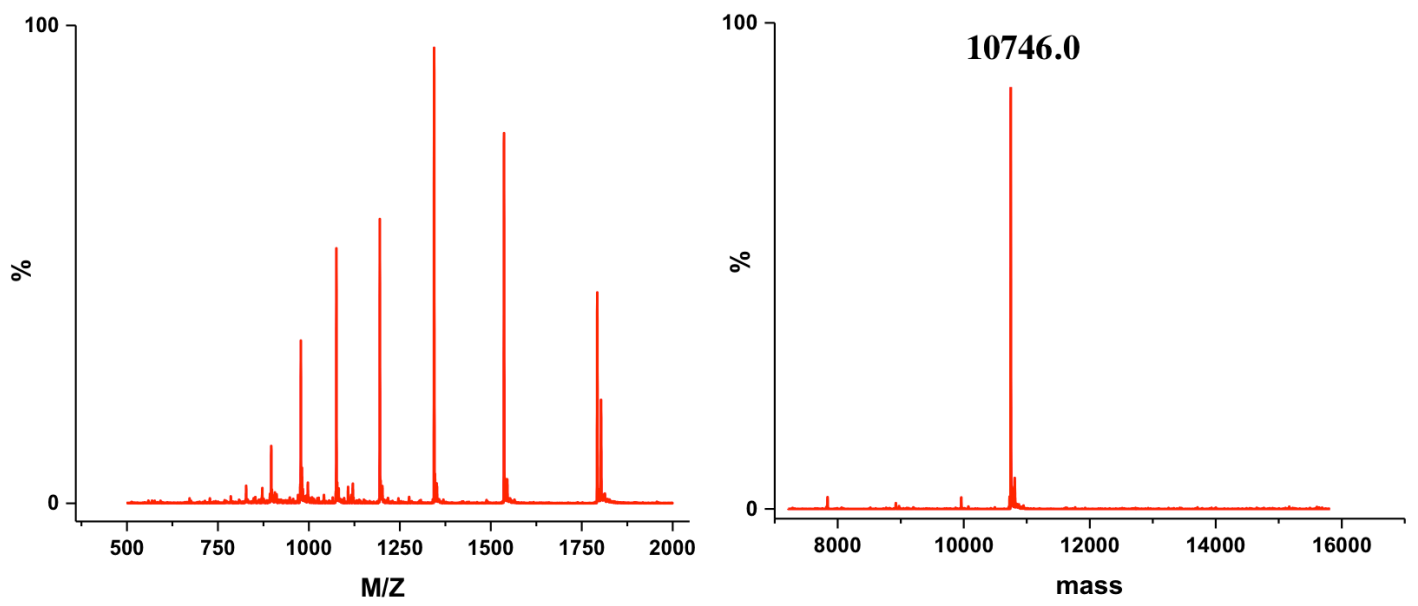

Figure S3. Representative ESI-MS of Nmar1307. The observed mass of apo-N.mar_1307 is 10,746 Da and the calculated mass is $10,747 \mathrm{Da}$. 

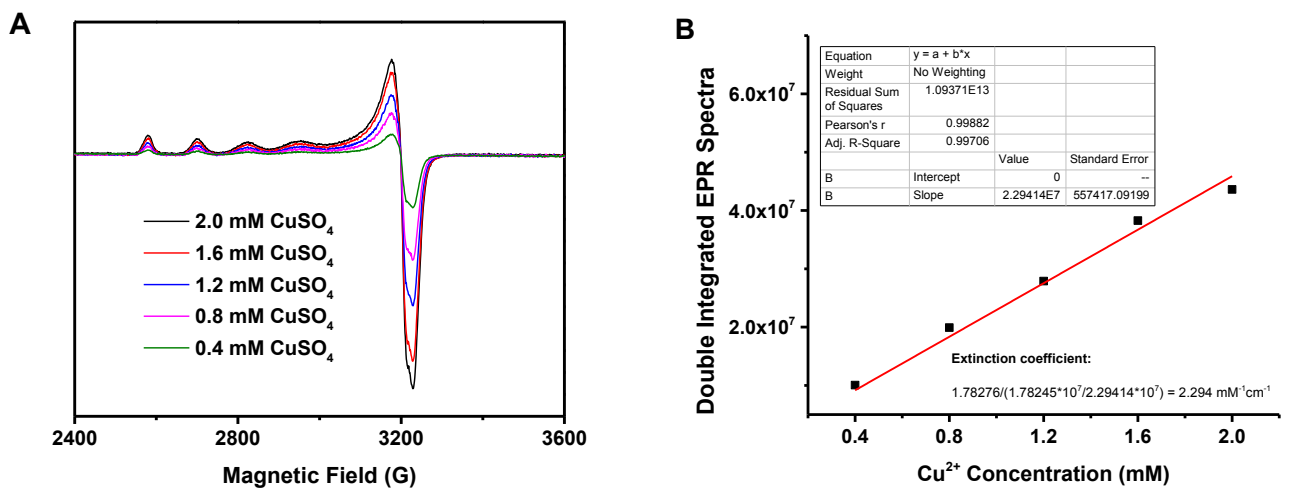

Figure S4. Cu(II)-Nmar1307 extinction coefficient determination by spin-counting EPR. (A) The EPR spectra of standard $\mathrm{CuSO}_{4}$ solution with known concentrations collected at $77 \mathrm{~K}$. (B) The total spins in samples were quantified by double integration of the spectrum. A standard curve was obtained by linear fitting of double integrated EPR spectra versus the $\mathrm{CuSO}_{4}$ concentrations. The concentration of $\mathrm{Cu}(\mathrm{II})-$ Nmar1307 was calculated by dividing the double integrated EPR spectrum of $\mathrm{Cu}(\mathrm{II})-\mathrm{Nmar} 1307$ by the slope of the linear fitting. UV-vis spectrum of $\mathrm{Cu}(\mathrm{II})-\mathrm{Nmar} 1307$ was taken and its extinction coefficient ( $2294 \mathrm{M}^{-1} \mathrm{~cm}^{-1}$ at $558 \mathrm{~nm}$ ) was calculated based on the absorption intensity and concentration of $\mathrm{Cu}(\mathrm{II})-$ Nmar1307.

(a)

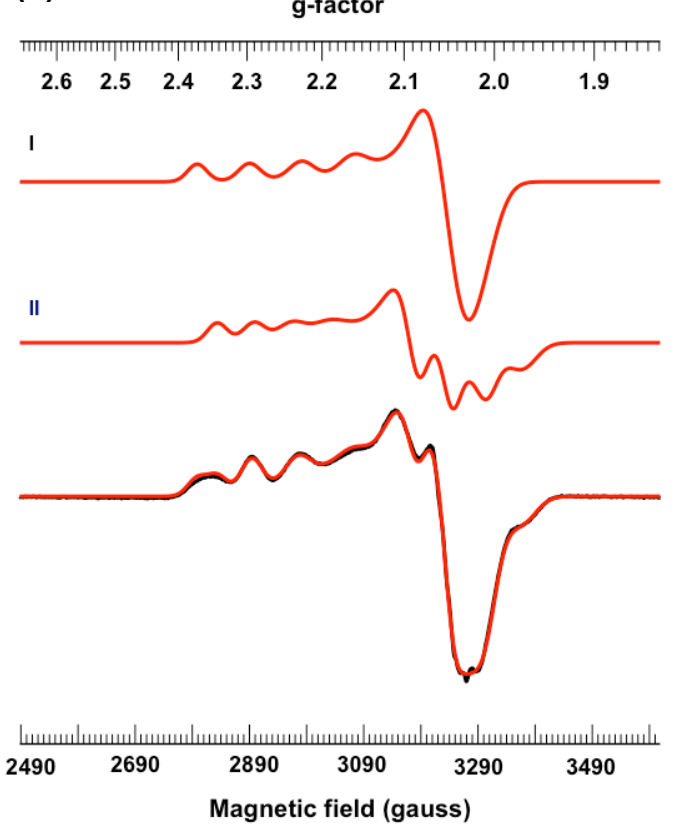

(b)

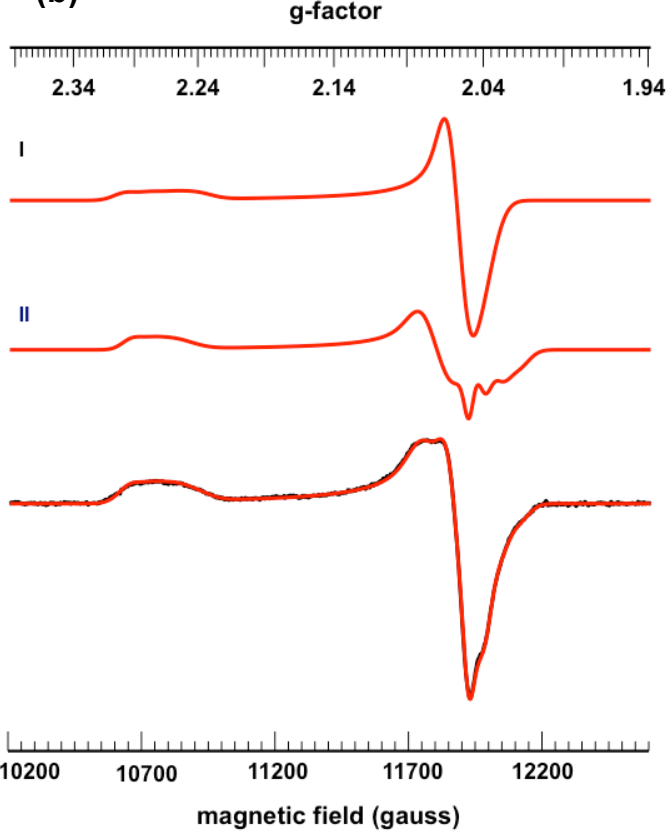

Figure S5. (a) EPR simulation of species I and II observed in X-band EPR of Nmar1307. The overall simulation and the experimental data are overlaid at the bottom of the figure. X-band EPR was collected at $77 \mathrm{~K}$, power of $1.0 \mathrm{~mW}$ and modulation of 4 gauss. (b) EPR simulation of species I and II observed in Qband EPR of Nmar1307. The overall simulation and the experimental data are overlaid at the bottom of the figure. Q-band EPR was collected at $77 \mathrm{~K}$, power of $0.046 \mathrm{~mW}$ and modulation of 8 gauss. 
(a)

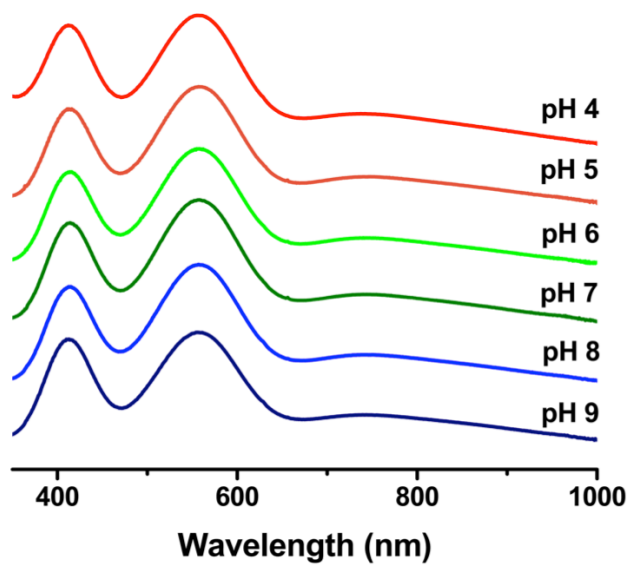

(b)

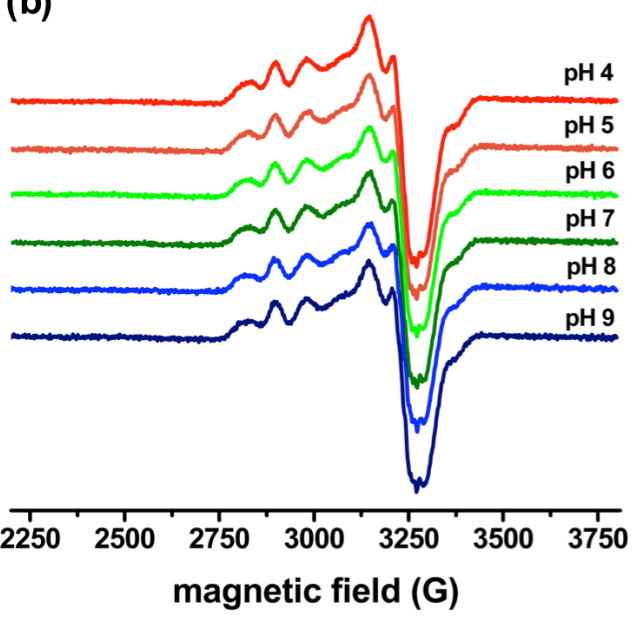

Figure S6. (a) UV-vis absorption spectra of $\mathrm{Cu}(\mathrm{II})$-Nmar1307 at different $\mathrm{pH}$ values. $\mathrm{Cu}(\mathrm{II})$-Nmar1307 was exchanged into universal buffer (UB buffer, containing $50 \mathrm{mM} \mathrm{NH}_{4} \mathrm{OAc}, 40 \mathrm{mM}$ MOPS, $40 \mathrm{mM}$ MES and $40 \mathrm{mM}$ Tris) which spans a wide range of $\mathrm{pH}$ with the same composition of buffer ions. (b) X-band EPR spectrum of $\mathrm{Cu}(\mathrm{II})-\mathrm{Nmar} 1307$ at different $\mathrm{pH}$ values. $0.77 \mathrm{mM} \mathrm{Cu}(\mathrm{II})-\mathrm{Nmar1307}$ at different $\mathrm{pHs}$ with $20 \%$ glycerol was quickly frozen in liquid nitrogen. Frequency: $9.29 \mathrm{GHz}$. Power: $1.0 \mathrm{~mW}$. Field modulation: $4.0 \mathrm{G}$. Temperature: $77 \mathrm{~K}$.

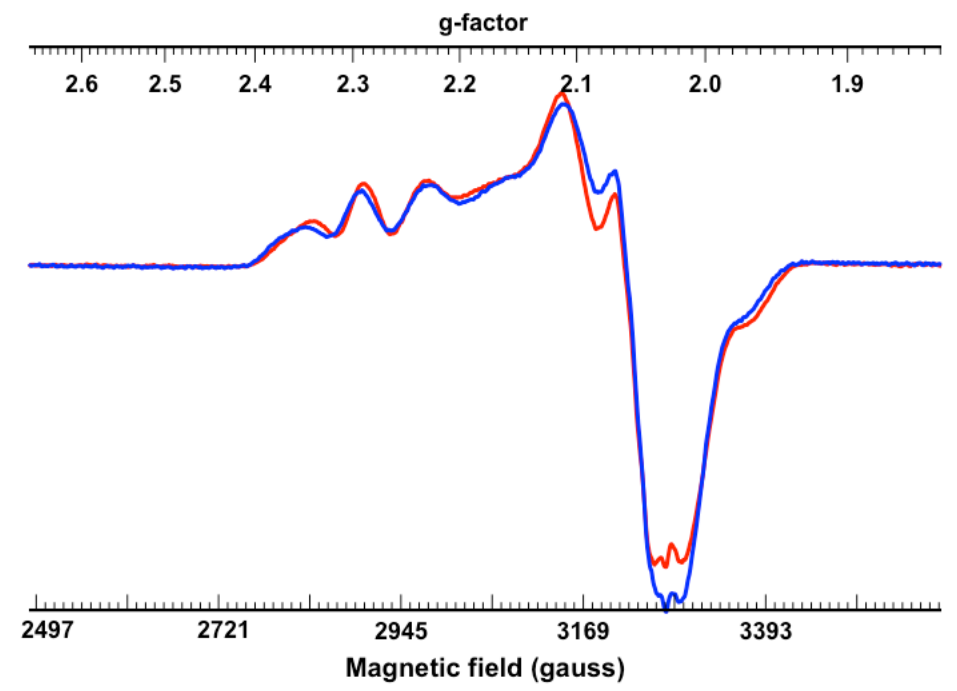

Figure S7. EPR of $\mathrm{Cu}(\mathrm{II})-\mathrm{Nmar} 1307$ at tris $\mathrm{HCl} \mathrm{pH} 8$ with $0 \%$ (blue) and $60 \%$ (red) glycerol. The data was collected at $77 \mathrm{~K}$, power of $1.0 \mathrm{~mW}$ and modulation of 4 gauss. The spectra are scaled to have the same double integrals. 


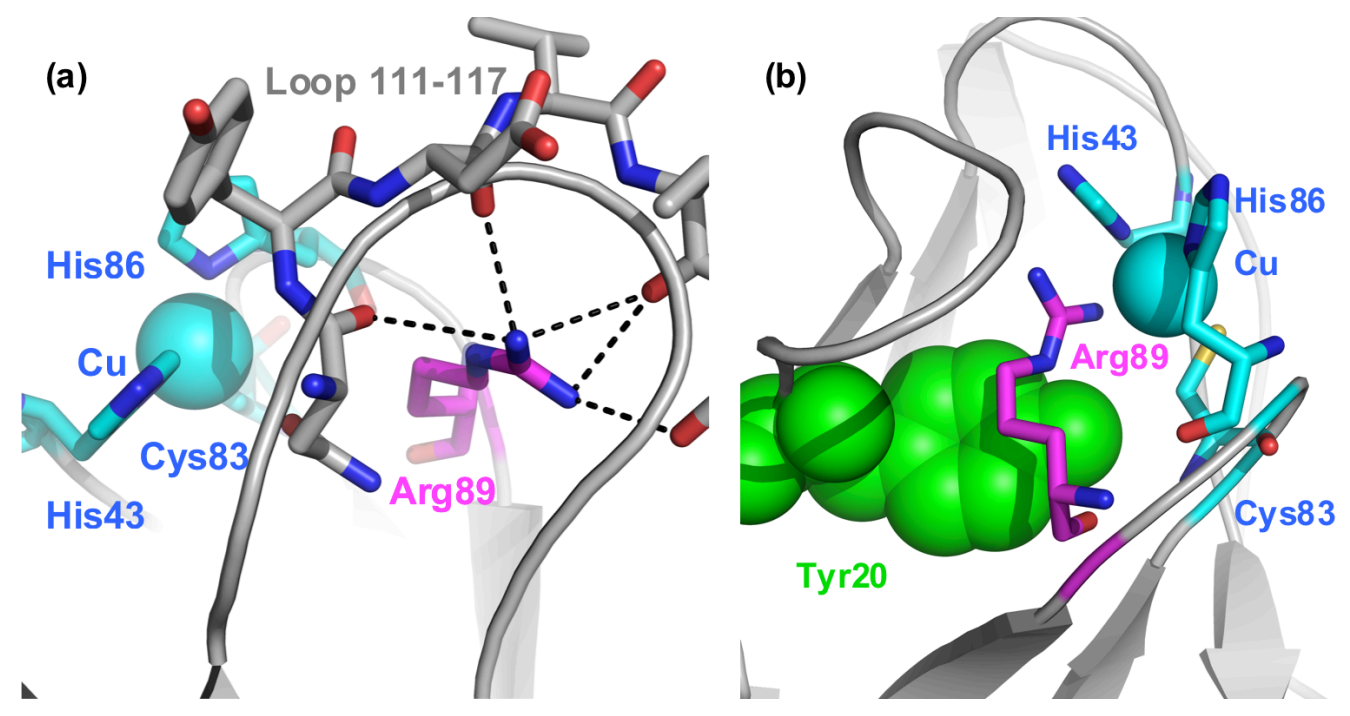

Figure S8. (a) The axial Arg (shown in magenta) is locked in a position away from the $\mathrm{Cu}$ binding site through multiple electrostatic interactions (shown as dashed lines) with residues in an adjacent loop (shown as gray sticks). (b) Tyr20 (green spheres) sterically blocks the axial Arg. The copper ion is shown as a cyan sphere and its ligands as cyan sticks.

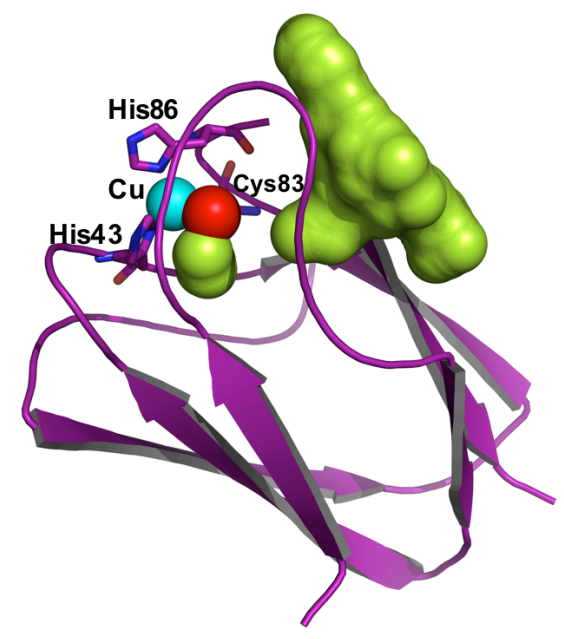

Figure S9. Possible entrance of water into the $\mathrm{Cu}$ binding site. The $\mathrm{Cu}$ ion is shown as a cyan sphere and the primary ligands are shown as magenta sticks. The red sphere is the axial water ligand. The green spheres show a "hole" in the protein that can fit an average atom in them. The collection of these empty holes demonstrates a possible "tunnel" for entrance of the axial water (red sphere) into the $\mathrm{Cu}$ binding site. 

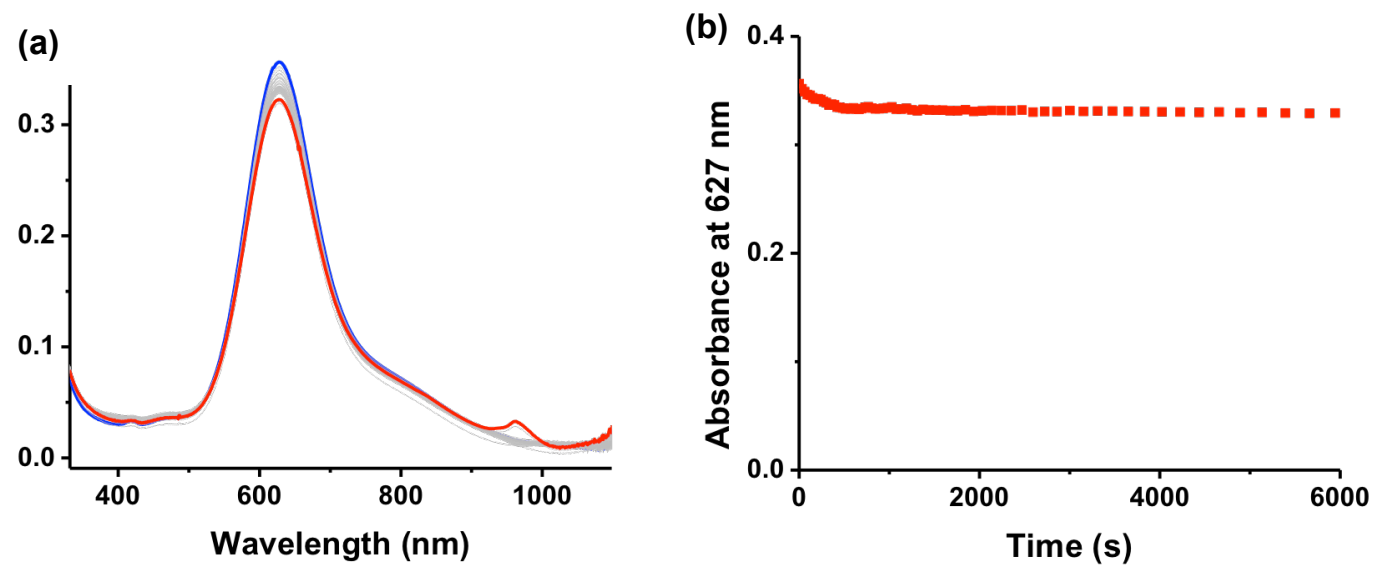

Figure S10. UV-vis spectroscopic study of $\mathrm{Cu}(\mathrm{II})-\mathrm{WTAz}$ reaction with NO. (a) UV-vis spectra of $70 \mu \mathrm{M}$ $\mathrm{Cu}(\mathrm{II})-\mathrm{WTAz}$ reacting with 5 eq. NO in $50 \mathrm{mM}$ BisTris pH7.0 buffer. (b) Time trace of the reaction based on monitoring the absorbance at $625 \mathrm{~nm}$.

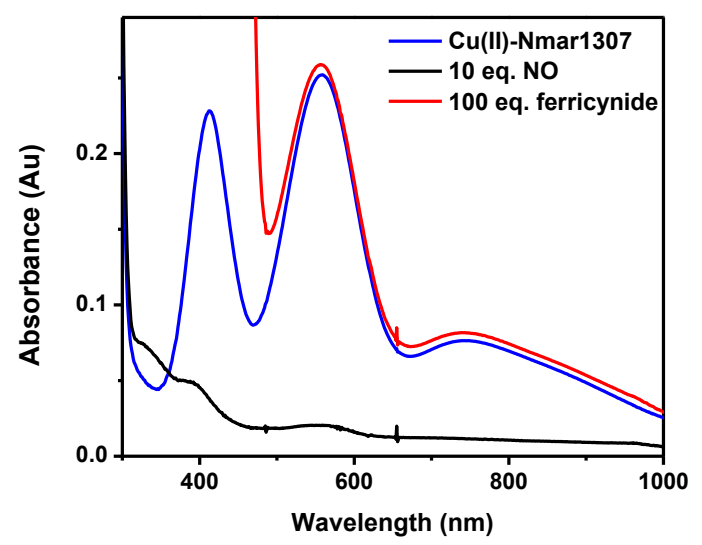

Figure S11. Reaction of $\mathrm{Cu}(\mathrm{I})-\mathrm{Nmar} 1307$, generated from reaction with $\mathrm{NO}$, with ferricyanide. An almost quantitative recovery of $\mathrm{Cu}$ (II) absorbance suggests that the site is intact. To $1.0 \mathrm{ml}$ of $116 \mu \mathrm{M} \mathrm{Cu}$ (II)Nmar1307 solution (shown in blue), 6.5 molar equivalents of Proli NONOate solution (from $60 \mathrm{mM}$ Proli stock solution in $10 \mathrm{mM} \mathrm{NaOH}$ ) was added at room temperature under stirring. After the color of the solution changed from purple to colorless (shown in black), 130 molar equivalents of potassium ferricyanide (from $1 \mathrm{M}$ stock of potassium ferricyanide in water) was added under stirring (shown in red). 

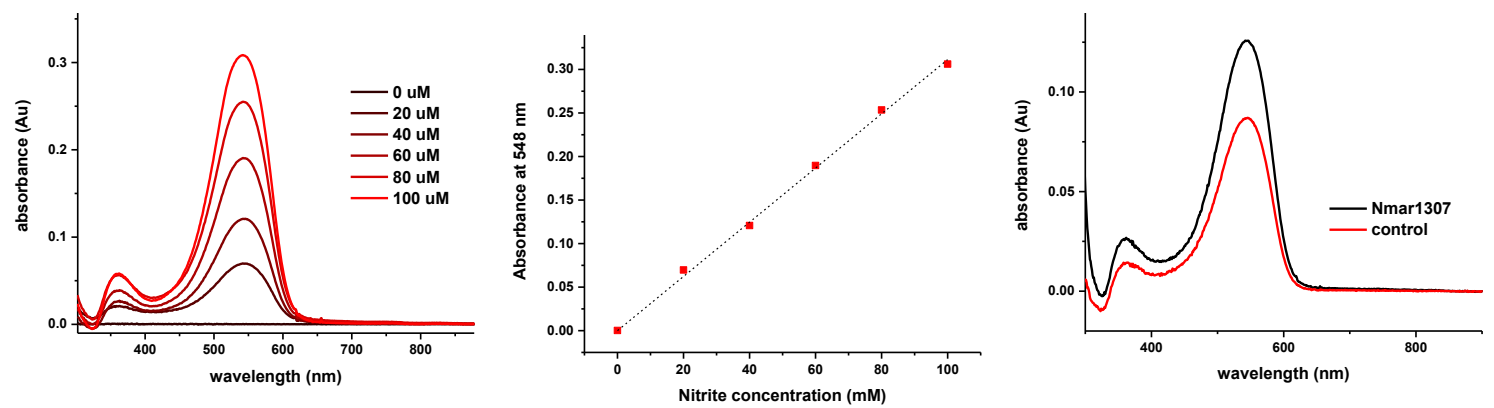

Figure S12. (a) , (b) show standard curve of Griese reagent for $\mathrm{NO}_{2}^{-}$production. (c) Production of $\mathrm{NO}_{2}^{-}$in buffer control $(27.9 \mu \mathrm{M})$ compared with Nmar1307 $(40.2 \mu \mathrm{M})$ after 30 min time with starting $200 \mu \mathrm{M}$ concentration of NO. The background $\mathrm{NO}_{2}{ }^{-}$production in buffer is due to side reaction of NONOate.
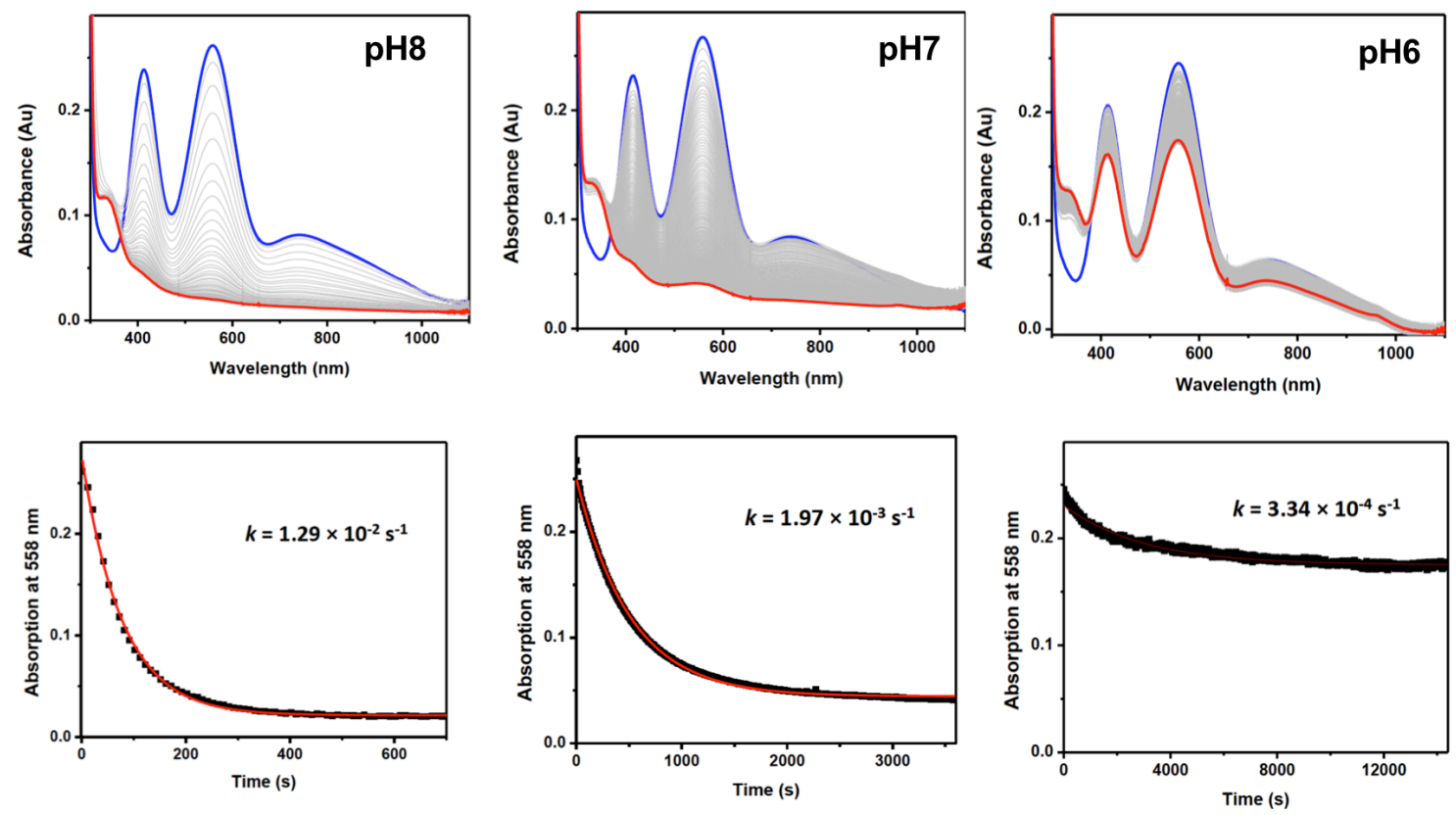

Figure S13. PH-dependent activity assay of Nmar1307. All the reactions are performed at saturated NO concentrations $(2 \mathrm{mM})$ with $150 \mathrm{uM}$ protein. To $1.0 \mathrm{ml}$ of $116 \mu \mathrm{M} \mathrm{Cu}$ (II)-Nmar1307 solution in $50 \mathrm{mM}$ MES at pH6.0, $50 \mathrm{mM}$ BisTris at $\mathrm{pH} 7.0$ or $50 \mathrm{mM}$ Tris at $\mathrm{pH} 8.0,13$ molar equivalents of Proli NONOate solution (from $60 \mathrm{mM}$ Proli NONOate stock solution in $10 \mathrm{mM} \mathrm{NaOH}$ ) was added at room temperature under stirring. The absorption decreasing at $558 \mathrm{~nm}$ was fitted in pseudo-first-order kinetics. 
A

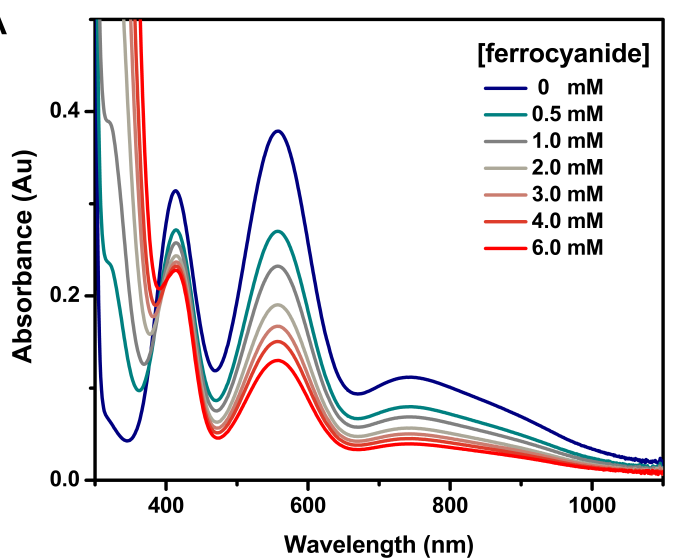

C

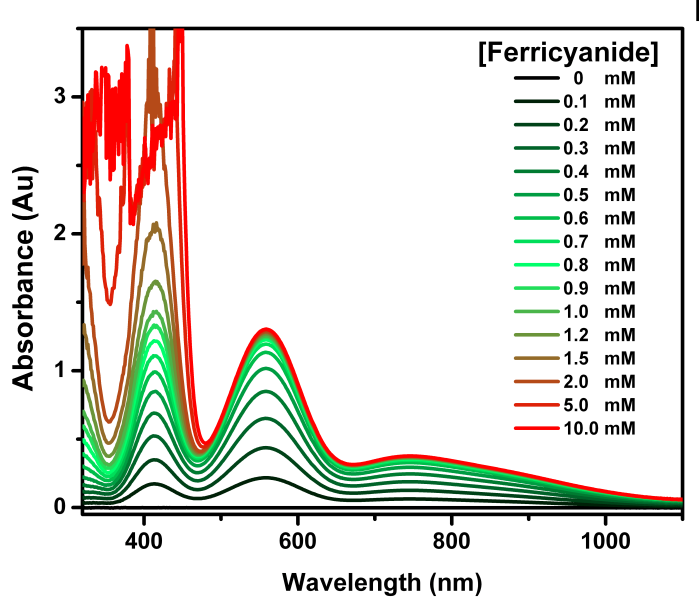

B

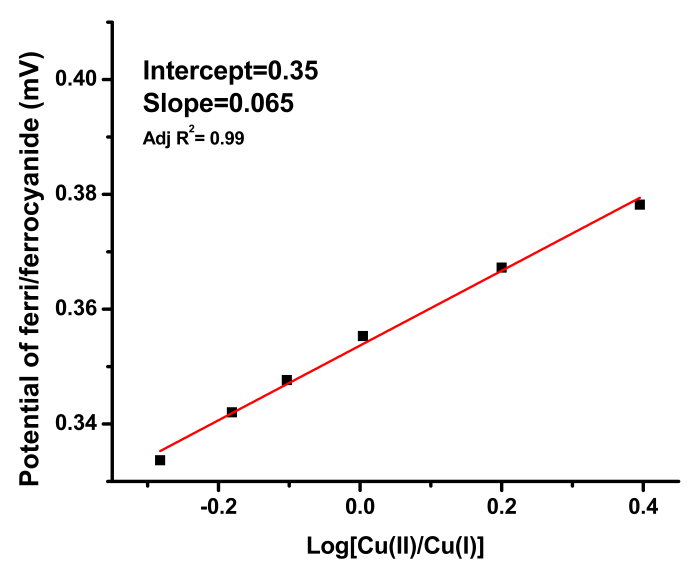

D

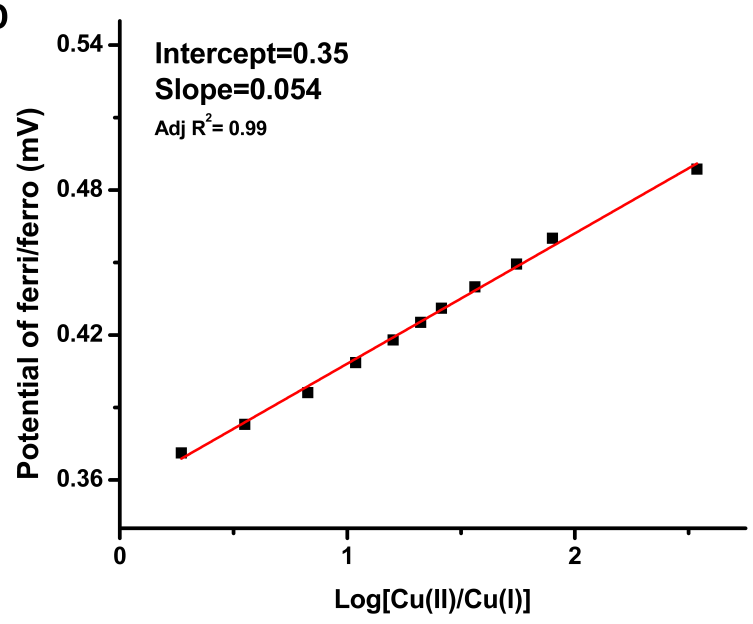

Figure S14. (A) Redox titration of $\mathrm{Cu}(\mathrm{II})$-Nmar1307 with different concentrations of ferrocyanide monitored by decrease in the absorption at $558 \mathrm{~nm}$ due to reduction of $\mathrm{Cu}(\mathrm{II})-\mathrm{Nmar} 1307$ by ferrocyanide at room temperature. (B) The reduction potential of $\mathrm{Cu}(\mathrm{II})$-Nmar_1307 was calculated based on Nernst equation by linear plotting the potentials of ferri/ferrocyanide redox pair versus $\log ([\mathrm{Cu}(\mathrm{II}) / \mathrm{Cu}(\mathrm{I})])$. The intercept $(354 \mathrm{mV})$ represents the reduction potential of $\mathrm{Cu}(\mathrm{II})-\mathrm{Nmar} 1307$ at $\mathrm{pH}$ 8.0. The slope of the fitting was $65 \mathrm{mV}$, close to the theoretic value $59 \mathrm{mV}$. (C) Redox titration of $\mathrm{Cu}(\mathrm{I})-\mathrm{Nmar} 1307$ with different concentrations of ferricyanide monitored by increase in the absorption at $558 \mathrm{~nm}$ due to oxidation of $\mathrm{Cu}(\mathrm{I})-\mathrm{Nmar} 1307$ by ferricyanide at room temperature. (D) The reduction potential of $\mathrm{Cu}(\mathrm{II})-\mathrm{Nmar} 1307$ was calculated based on Nernst equation by linear plotting the potentials of ferri/ferrocyanide redox pair versus $\log ([\mathrm{Cu}(\mathrm{II}) / \mathrm{Cu}(\mathrm{I})])$. The intercept $(354 \mathrm{mV})$ represents the reduction potential of $\mathrm{Cu}(\mathrm{II})-\mathrm{Nmar} 1307$ at $\mathrm{pH}$ 8.0. The slope of the fitting was $65 \mathrm{mV}$, close to the theoretic value $59 \mathrm{mV}$. 

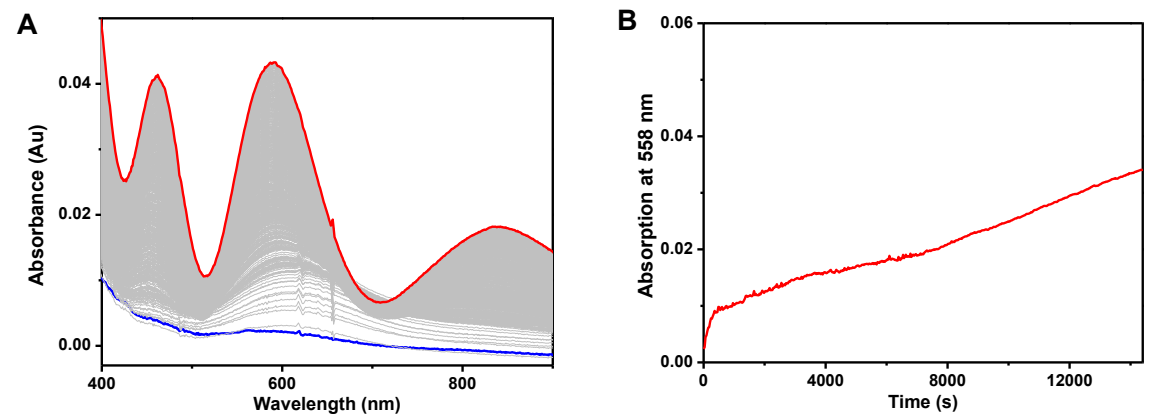

Figure S15. (A) Kinetic UV-vis of $\mathrm{Cu}(\mathrm{I})-\mathrm{Nmar} 1307$ upon reaction with 13 molar equivalents of $\mathrm{NO}_{2}^{-}$at $\mathrm{pH}$ 6. The blue trace is the initial spectrum and the red trace is the final spectrum after 4 hours. (B) Monitoring the increase in LMCT bands at $558 \mathrm{~nm}$.
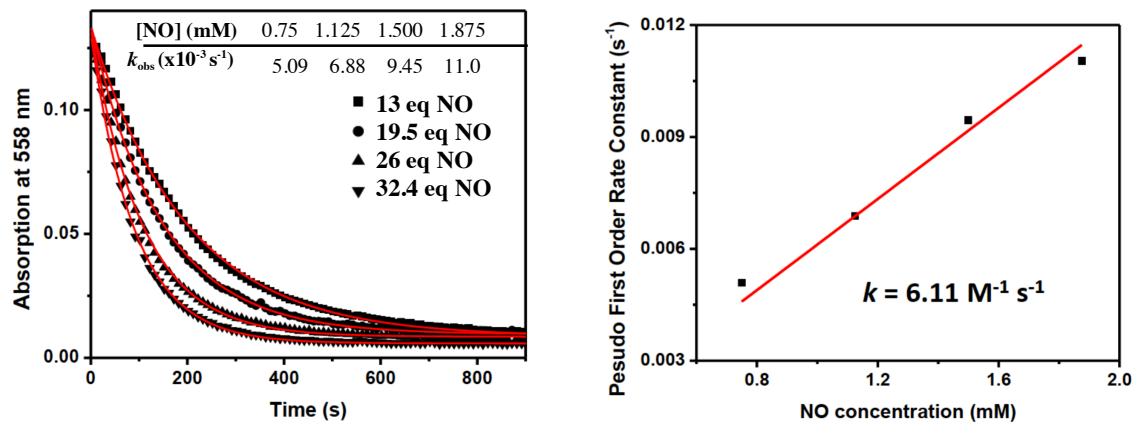

Figure S16. Reaction of Nmar1307 with different concentrations of NO under single turnover conditions and the observed $k_{\mathrm{obs}}$ for each concentration. Plotting the $k_{\mathrm{obs}}$ values vs concentration gives a second order rate constant of $6.11 \mathrm{M}^{-1} \mathrm{~s}^{-1}$ for the reaction. To $1.0 \mathrm{ml}$ of $58 \mu \mathrm{M} \mathrm{Cu}(\mathrm{II})-\mathrm{Nmar} 1307$ solution, 6.5, 9.7, 13 or 16.2 molar equivalents of Proli NONOate solution (from $60 \mathrm{mM}$ Proli stock solution in $10 \mathrm{mM} \mathrm{NaOH}$ ) was added at room temperature under stirring. The concentration of NO was calculated to be twice of the concentration of Proli NONOate (each Proli NONOate dissociates to form one proline and two NO molecules). The absorption decreasing at $558 \mathrm{~nm}$ was fitted in pseudo-first-order kinetics. The secondorder reaction rates between $\mathrm{Cu}(\mathrm{II})$-Nmar1307 and $\mathrm{NO}$ was calculated upon linear fitting pseudo-first-order reaction rates under varies concentrations of NO.

Tables:

Table S1. Data collection and refinement statistics of Nmar1307 crystal.

\begin{tabular}{|c|c|}
\hline Resolution range ( $(\AA)$ & $45.87-1.6(1.657-1.6)$ \\
\hline Space group & $\mathrm{P} 4_{1} 2_{1} 2$ \\
\hline Unit cell & $68.88768 .887184 .45 / 909090$ \\
\hline Unique reflections & $59603(5817)$ \\
\hline
\end{tabular}




\begin{tabular}{|c|c|}
\hline Completeness (\%) & $99.97(99.74)$ \\
\hline Mean I/sigma(I) & $17.74(5.31)$ \\
\hline Wilson B-factor & 18.70 \\
\hline R-work & $0.1703(0.2032)$ \\
\hline R-free & $0.1918(0.2411)$ \\
\hline Number of non-hydrogen atoms & 3609 \\
\hline Macromolecules & 3012 \\
\hline Ligands & 6 \\
\hline Water & 591 \\
\hline Protein residues & 384 \\
\hline RMS(bonds) & 0.006 \\
\hline RMS(angles) & 1.07 \\
\hline Ramachandran favored (\%) & 97 \\
\hline Ramachandran outliers (\%) & 0 \\
\hline Clashscore & 2.57 \\
\hline Average B-factor & 22.90 \\
\hline Macromolecules & 20.80 \\
\hline Ligands & 24.10 \\
\hline Solvent & 33.40 \\
\hline
\end{tabular}

Statistics for the highest-resolution shell are shown in parentheses.

Table S2. Relevant bond length near the Cu binding site of Nmar1307

\begin{tabular}{|c|c|c|c|c|c|}
\hline Atoms & Chain A $(\AA)$ & Chain B $(\AA)$ & Chain C $(\AA)$ & Chain D $(\AA)$ & $\begin{array}{c}\text { Average } \\
\text { distance }(\AA)\end{array}$ \\
\hline $\mathrm{S}_{\mathrm{Cys} 83^{-} \mathrm{Cu}}^{\gamma}$ & 2.23 & 2.26 & 2.26 & 2.24 & 2.25 \\
\hline
\end{tabular}




\begin{tabular}{|c|c|c|c|c|c|}
\hline $\mathrm{N}_{\mathrm{His} 43}^{\delta}-\mathrm{Cu}$ & 1.97 & 2.03 & 2.00 & 2.04 & 2.01 \\
\hline $\mathrm{N}_{\mathrm{His} 86}^{\delta}-\mathrm{Cu}$ & 2.05 & 2.05 & 2.07 & 2.09 & 2.07 \\
\hline $\mathrm{O}_{\mathrm{Pro} 42}-\mathrm{Cu}$ & 4.24 & 4.29 & 4.21 & 4.28 & 4.25 \\
\hline $\mathrm{O}_{\mathrm{Asn} 11}^{\delta}-\mathrm{Cu}$ & 3.95 & 3.90 & 3.95 & 3.88 & 3.92 \\
\hline $\mathrm{O}_{\text {Asn11- }}^{\delta} \mathrm{O}_{\text {water }}$ & 2.56 & 2.54 & 2.51 & 2.56 & 2.54 \\
\hline $\mathrm{O}_{\mathrm{Ty} 20}{ }-\mathrm{Cu}$ & 4.92 & 4.77 & 4.85 & 4.84 & 4.85 \\
\hline $\mathrm{O}_{\text {Tyr20 }}-\mathrm{O}_{\text {water }}$ & 3.05 & 2.96 & 2.95 & 2.92 & 2.97 \\
\hline $\mathrm{O}_{\text {water }}-\mathrm{Cu}$ & 2.24 & 2.21 & 2.26 & 2.27 & 2.25 \\
\hline
\end{tabular}

\section{References:}

(1) Hwang, H.; Ang, M.; Lu, Y. J. Biol. Inorg. Chem. 2004, 9, 489.

(2) Nilges, M. J.; MAtteson, K.; Bedford, R. L. In Biological Magnetic Resonance; Hemminga, M. A., Berliner, L., Eds.; Springer: New York, 2007.

(3) Adams, P. D.; Afonine, P. V.; Bunkoczi, G.; Chen, V. B.; Echols, N.; Headd, J. J.; Hung, L. W.; Jain, S.; Kapral, G. J.; Grosse Kunstleve, R. W.; McCoy, A. J.; Moriarty, N. W.; Oeffner, R. D.; Read, R. J.; Richardson, D. C.; Richardson, J. S.; Terwilliger, T. C.; Zwart, P. H. Methods 2011, 55, 94.

(4) Emsley, P.; Lohkamp, B.; Scott, W. G.; Cowtan, K. Acta Crystallogr. D: Biol. Crystallogr. 2010, 66, 486.

(5) Humphrey, W.; Dalke, A.; Schulten, K. J. Mol. Graph. 1996, 14, 33.

(6) Ho, B. K.; Gruswitz, F. BMC Struct. Biol. 2008, 8, 49.

(7) Saavedra, J. E.; Southan, G. J.; Davies, K. M.; Lundell, A.; Markou, C.; Hanson, S. R.; Adrie, C.; Hurford, W. E.; Zapol, W. M.; Keefer, L. K. J. Med. Chem. 1996, 39, 4361. 